Original Research Paper

\title{
Effects of Sargassum crassifolium Extract Formula as Biostimulant on Growth and Yield of Glycine max L. Merill
}

\author{
Zozy Aneloi Noli* \& Muhammad Azwar \\ Biology Department, Mathematics and Natural Sciences Faculty, Universitas Andalas, Limau Manis \\ Padang, Indonesia
}

\author{
Article History \\ Received : July $28^{\text {th }}, 2021$ \\ Revised : August $25^{\text {th }}, 2021$ \\ Accepted : September 05 ${ }^{\text {th }}, 2021$ \\ Published : September $14^{\text {th }}, 2021$ \\ *Corresponding Author: \\ Zozy Aneloi Noli, \\ Andalas Universiry, Padang, \\ Indonesia \\ Email: zozynoli@sci.unand.ac.id
}

\begin{abstract}
The research about the Effect of Sargassum crassifolium Extract Formula as Biostimulant to Increase Growth and Yield of Glycine $\max$ L. Merill was conducted from February until June 2020 at the warehouse of Plant Physiology Laboratory, Department of Biology, Faculty of Mathematics and Natural Sciences, Andalas University, Padang. The research aims to evaluate the effectiveness of liquid and powder extract formula of $S$. crassifolium as biostimulant on the growth and yield of soybean (Glycine max L. Merill). The research was conducted by an experimental method arrange in a Completely Randomized Design (CRD). The experiment consisted of 3 treatments. Each treatment was laid out with nine replications. The treatments tested were control, liquid extract $(0.4 \%)$, powder extract $(1.6 \mathrm{~g} / \mathrm{L})$. The results showed that the application of liquid extract gave a higher tendency towards the improvement of the root system, fresh and dry weight, chlorophyll content, and 100 seeds weight of soybean plant. While the powder extracts shown the best result on the total seed weight. Both of extract formula had the potential to be used to increase growth and yield of soybean.
\end{abstract}

Keywords: Biostimulant, formulation, Glycine $\max$ (Merill.), Sargassum crassifolium, Yield.

\section{Introduction}

Biostimulants are organic compounds both natural and synthetic that are not included in the fertilizer group intended to be applied to cultivated plants. This compound is able to promote plant growth (Abbas, 2013), vigor, enhance nutrients and water uptake (Brown and Sebastian, 2015), and increase the response of plants to environmental stress (Du Jardin, 2012). Biostimulants can be obtained from organic ingredients. These organic substances include humic substances (HS), microbial inoculants, amino acids, inorganic salts, chitin derivatives, chitosan, and seaweed extracts (Nardi et al., 2016).

Seaweed as a biostimulant has been widely used to promote plant growth (Du Jardin, 2020). Considering that Indonesia's marine areas have abundant seaweed resources, it is important to explore the benefits contained in it. 8,642 species of seaweed were recorded in the world and The Data of the Ministry of Maritime Affairs and Fisheries (2015) shows that there are 555 species of seaweed in the coastal of Indonesia. According to Hadi, Zakaria, and Syam (2016) five species of seaweed distributed along the coast of Nirwana, West Sumatra are Halimeda sp., Padina minor, Sargassum crassifolium, Sargassum cristaefolium and Turbinaria decurrens which belong to the group of brown seaweed (Phaeophyta). Screening the effectiveness of five species of seaweed has been carried out by Noli et al. (2018 a), and from the experiment, Sargassum crassifolium well identified as an important source of biostimulant to increase the germination and growth of several crop plants (Noli et al., 2018 b). 


\section{Materials and Method}

\section{Experimental Site and Time}

Research on Effect Sargassum crassifolium Formula Extract as Biostimulant to Increase Growth and Yield of Soybean (Glycine max L. Merill) was conducted from February until June 2020 at the warehouse of Plant Physiology Laboratory, Department of Biology, Faculty of Mathematics and Natural Sciences, Universitas Andalas, Padang.

\section{Experimental Design}

The research was conducted by an experimental method arrange in a Completely Randomized Design (CRD). The experiment consisted of 3 treatments. Each treatment was laid out with nine replications. The treatments tested were:
A. Control,
B. Liquid extract $(0.4 \%)$,
C. Powder extract $(1.6 \mathrm{~g} / \mathrm{L})$.

\section{Research procedure \\ Sample Collection}

$S$. crassifolium were collected $1000 \mathrm{~g}$ from Nirwana Beach, a coastal area, about $11 \mathrm{~km}$ from Padang City, West Sumatra. S. crassifolium sample was picked with hand and immediately washed with seawater to remove sand and other and washed again with tap water to remove the salt then the seaweeds were shade dried under the sun for \pm 5 days.

\section{Powder Extract Preparation}

The dried $S$. crassifolium crushed using a grinder to form powder, then weighed according to treatment then immersed in hot water with a ratio of samples and water (1: $20(\mathrm{w} / \mathrm{v}))$, then homogeneous with a shaker for 24 hours at room temperature then filtered. The resulting filtrate was dissolved in 1-liter of water and put in a glass bottle (Norra et al., 2016).

\section{Liquid Extract Preparation}

The dried $S$. crassifolium sample was then ground using a grinder until it becomes a coarse powder. Furthermore, the sample was weighed and then dissolved with distillate water in a ratio of 1:20 (w / v). Samples were heated in an autoclave at $121^{\circ} \mathrm{C}$ for 30 minutes. Then the sample was filtered. The hot filtrate was filtered and allowed to cool down at room temperature. Finally, the filtrate was centrifuged at $10,000 \mathrm{rpm}$ for 15 minutes. The supernatant was considered as $100 \%$ liquid extract from S. crassifolium (Kavipriya et al., 2012).

\section{Parameters}

Data collection of plant height and number of leaves were carried out every week, measurements of plant chlorophyll content were carried out four weeks after extract application using a spectrophotometer. Root length, weight of 100 seeds, total seeds weight, fresh weight and dry weight parameters were calculated at the end of the observation.

\section{Data analysis}

The growth and yield parameters were examine using analysis of variance (ANOVA) using the SPSS, IBM statistic SPSS 21 Version Software. If the effect of treatment was significantly different, continued with Duncan New Multiple Range Test (DNMRT) test at 5\% significant level. Some parameters were also examine using parametric description.

\section{Results and Discussions}

The Average of Plant Height, Root Length, Number of Leaves

Table 1. The Average of Plant Height, Root Length, Number of Leaves in Several Treatments of S. Crassifolium Extract Formula

\begin{tabular}{lccc}
\hline & $\begin{array}{c}\text { Plant } \\
\text { Height } \\
(\mathrm{cm})\end{array}$ & $\begin{array}{c}\text { Root Length } \\
(\mathrm{cm})\end{array}$ & $\begin{array}{c}\text { Number } \\
\text { of Leaves }\end{array}$ \\
\hline A (Control) & $52 \mathrm{a}$ & $148.5 \mathrm{a}$ & $33.6 \mathrm{a}$ \\
B (Liquid) & $52.8 \mathrm{a}$ & $180.54 \mathrm{~b}$ & $35.4 \mathrm{a}$ \\
C (Powder) & $51.7 \mathrm{a}$ & $157.54 \mathrm{ab}$ & $34.1 \mathrm{a}$ \\
\hline
\end{tabular}

Note: Mean values $( \pm \mathrm{SE})$ in a column with different letter(s) are significantly different according to Duncan's multiple range test $(\mathrm{P}<.05)$.

Based on the results of the statistical analysis presented in Table 1. It can be seen that the application of several S. crassifolium extract formulas applied to soybean plants had no significant influence on the plant height and number of leaves of soybean plants, but it has a significant effect on root length parameter. 
However, root length in the treatment which applied with the extract in a liquid formula (liquid extract) showed the only treatment with the best performance on root length compared to the control. Table 1 showed that the liquid extract and powder extract exert a similar effect on root length observation.

According to Sutharsan et al. (2017) the application of seaweed extract applied to soybean crops can stimulate the improvement of the plant rooting system. In line with this, Katarzyna et al. (2016) reported that liquid extracts contained more $\mathrm{P}, \mathrm{S}$ and $\mathrm{B}$ compounds while the powder extract contained large amounts of $\mathrm{Ca}, \mathrm{Mg}$ and $\mathrm{Fe}$ compounds in the group of Polysiphonia, Ulva, and Cladophora seaweed. Billard (2013) also reported that the application of AZAL5 extract (extract from Aschopyllum nodosum seaweed) applied to Brassica napus L. plant is able to increase the concentrations of several nutrients $(\mathrm{Na}, \mathrm{Mn}, \mathrm{Cu}$, and $\mathrm{Mg}$ ) which are excellent for supporting the growth of such plants.

Seaweed extract is known to contain components of bioactive compounds in the form of growth regulatory hormones, including gibberellins, cytokinin, auxin and abscisic acid. The hormone is also used as a precursor to producing compounds that can stimulate growth (Stirk et al., 2014). Previous research has reported that cytokinin, auxins, abscisic acid, gibberellins and a class of other similar hormone groups of compounds, such as sterols and polyamines, have been identified in seaweed extracts especially in brown seaweed groups.

\section{The Average of Fresh Weight, Dry Weight, and Number of Pods}

The average of fresh weight, dry weight, and the number of pods treated with several $S$. crassifolium extract formulas can be seen in Figure 3.

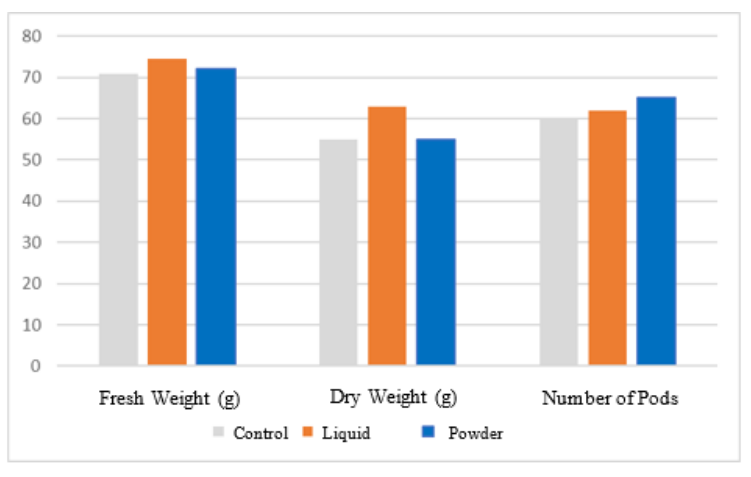

Figure 3. The Average of Fresh Weight, Dry Weight and Number of Pods in Several $S$. crassifolium Extract Formula Treatments

The result of the process of growth and development can be observed from the fresh weight and dry weight. The definition of fresh weight is the result of measurements of the fresh weight of plant biomass as the accumulation of materials produced during the growth (Buntoro et al., 2014). Fresh weight is defined as the weight recorded as soon as part or all of the plants is harvested so that the content of water and carbohydrates stored in the plant tissue can be observed, while dry weight is the weight recorded after drying the plant or part of the plant at a temperature higher than the ambient air temperature (for instance, about $65-100^{\circ} \mathrm{C}$ ) to drive off the water contained in the plant. This is overall can illustrate the results of photosynthesis in plants (Huang et al., 2019). The number of pods is the amount of fruit produced by soybean crops that is calculated shortly after part or all of the plant is harvested. This is done to find out the results of photosynthates obtained by soybeans during the growth period (Desnilia et al., 2014).

Based on Figure 3. the application of liquid extract formulas provides a tendency to produce better results compared with the powder extract formulas, presumably this was because the compounds contained in both extracts have different component proportions. This was thought to be due to extraction techniques on both different types of formulas. In the process of extraction of liquid formulas, heating techniques were performed in high temperatures using autoclave and the resultant solution was stored in liquid form, while in powder formulas, extracts were stored in powder form and dissolved before application to soybean plants. In liquid formulas, 
S. crassifolium extract was heated using autoclave with a temperature of $121^{\circ} \mathrm{C}$ for 30 minutes then centrifuged to obtain its supernatant. While in the powder formula, $S$. crassifolium extract was only heated with hot water shortly before application. This can affect the number of components contained in extracts that are successfully extracted which makes the effectiveness of their work different when applied to soybean crops. This difference in extraction techniques exerts a different influence on the results of the isolation of active component compounds that exist in plants (Yang et al., 2011). In previous research, Katarzyna et al. (2016) reported that high-temperature liquid extraction is more effective and efficient. It aims to break cell walls so that chemical compounds contained in seaweed can dissolve.

The results of this research showed a higher tendency towards the parameter of fresh weight, dry weight and the number of pods applied with $S$. crassifolium extract compared to the control. In line with this, the same results were also obtained from Abdalla (2013) which reported that the spraying of biostimulant from leaf extracts and branch extracts of Moringa oleifera plants applied twice ( 7 and 14 days after planting) had a significant influence on fresh weight, dry weight and plant height of arugula plant (Eruca vesicaria subsp. sativa).

\section{Chlorophyll Content in Soybean Plants}

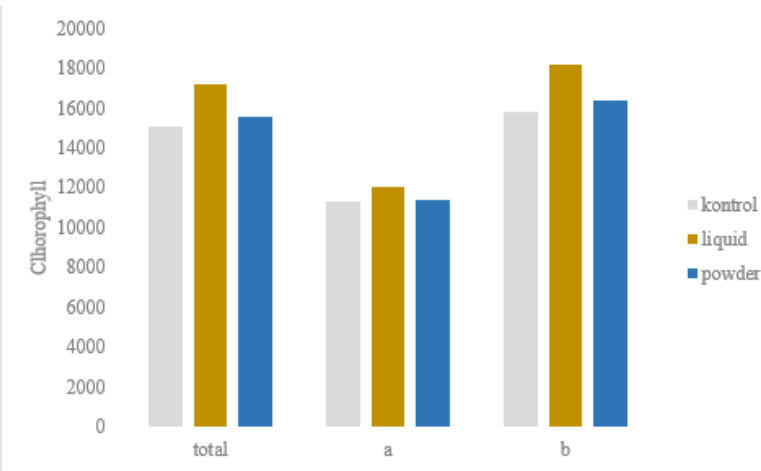

Figure 4. Chlorophyll Content in Soybean Crops given Several S. crassifolium Extract Formulas.

Based on Figure 4. it can be seen that the treatment of several extract formulas exerts an influence on chlorophyll content in soybean crops compared to controls. The results when compared between the two types of extract formulas, it was identified that liquid extracts have a higher propensity for chlorophyll levels than powder extracts. This is in accordance with the results of research conducted by Tandon (2015), that the application of Aschopyllum nodosum extract is able to increase the total chlorophyll by $30 \%$ in spinach plants. In research conducted by Norra et al. (2016) liquid extracts from red watermelon (Citrullus lanatus) have higher antioxidant components compared to powder extracts. Immersion of sea rambai (Sonneratia caseolaris) leaf extract also shows the highest yield on liquid extract when compared to powder extract.

Some previous studies have widely reported the application of biostimulants to increased chlorophyll content. Seaweed extract from Aschopyllum nodosum is known to increase the total photosynthetic pigments, including chlorophyll and carotenoid content in soybean crops. Foliar application of seaweed extract from Ecklonia maxima may increase chlorophyll a, chlorophyll b, total chlorophyll and carotenoid concentration in cabbage (Brassica oleracea) (Rengasamy, 2016). Kasim et al. (2015) in his research reported that seaweed extracts from Sargassum and Ulva, which are applied to seeds, help maintain photosynthetic pigments in wheat under drought deftness. The application of liquid extracts from Senecio johnstonii is able to increase chlorophyll pigments $\mathrm{a}$ and $\mathrm{b}$ in tomato plants when applied directly to leaves and soil (Kumari, 2011). Kappaphycus alvarezii red seaweed extract is able to increase chlorophyll content in corn crops. In accordance with, Rengasamy (2010) also reports that liquid extracts can increase the number of branches and concentrations of photosynthetic pigments as well as increase the chlorophyll content of plants. Liquid extracts of Ascophyllum nodosum applied to tomato leaves may increase chlorophyll content compared to tomato plant control. Osman and Salem (2011) also reported that the application of liquid extracts of lettuce (Lactuca sativa) significantly increases chlorophyll levels $\mathrm{a}$ and $\mathrm{b}$ in sunflowers (Helianthus annuus L.).

\section{The Average Weight of 100 Seeds and Total Seed Weight}


Based on the observations that have been carried out, the average weight data of 100 seeds and the total seed weight gave with the treatment of several extract formulas on soybean plants can be seen in Figure 5 and 6 below.

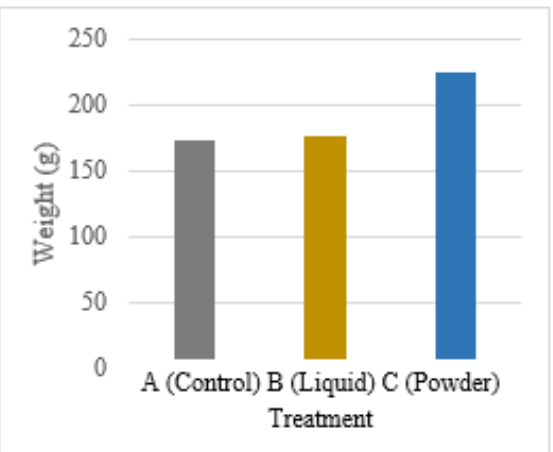

Figure 5. Total Seed Weight with Several Treatment Formula Extract $S$. crassifolium.

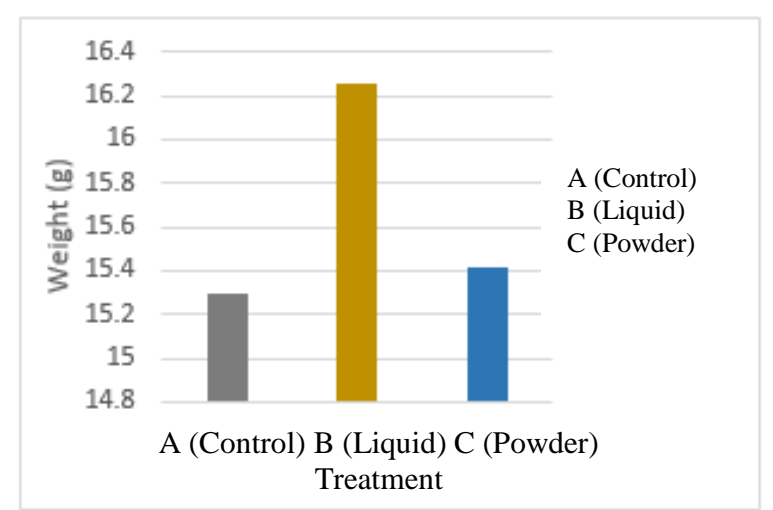

Figure 6. Average Weight of 100 Seeds with Several Treatment Formula Extract $S$. crassifolium.

According to the data presented in Figure 5 and 6, it can be known that the treatment of the S. crassifolium extract formula provides a higher yield tendency towards the total seed weight and weight of 100 soybean seeds compared to the control treatment. However, there were different effects shown by each extract formula. The treatment of powder extract application shows a higher total weight of soybean seeds compared to liquid extracts and controls. This is in line with the parameters of the number of pods in the powder extract application treatment which affects higher yields compared to other treatments (Figure 3.). It is important to note that the result indicates the application of liquid extract $S$. crassifolium is able to improve the better quality of soybean seed produced so that the average weight of 100 soybean seeds is higher compared to other treatments.

In general, both formulations of seaweed extract treatment $S$. crassifolium were able to increase seed growth. It is due to the previous parameters; these two extracts tend to provide good results against chlorophyll content. Increasing content in soybean crops will automatically affect the increase in the results of photosynthesis of crops. This increased seed growth result is due to a significant increase in soluble carbohydrates, soluble proteins and total amino acids compared to control (Ronga et al., 2019) as a result of optimal photosynthesis results. These results suggest that the application of $S$. crassifolium has an influence on the total production of soybean crops. The increase in yields may be due to the absence of plant growth regulators and macro and micro nutrients contained in extracts from $S$. crassifolium. According to Sasidharan et al. (2019) the improvement in total seed weight is due to an increase in absorbed nutrients and the activity of enzymes formed during fruit formation.

\section{Conclusion}

Based on this research, we can conclude that the application of both formulas had no significant results on the statistic level, but the liquid extract gave a higher tendency towards the improvement of the root system, fresh and dry weight, chlorophyll content, and 100 seeds weight of soybean plant. While the powder extracts shown the best result on the total seed weight.

\section{Aknowledgement}

The authors thank to Biology Department, Faculty of Mathematics and Natural Sciences, Andalas University for the facility support of this experiment.

\section{References}

Abbas, S.M. (2013). The Influence of Biostimulant on The Growth and on The Biochemical Composition of Vicia faba CV. Giza 3 beans. Romanian 
Biotechnological Letters, 18(2); 80618068 .

Abdalla, M.M. (2013). The Potential of Moringa oleifera Extract as a Biostimulan in Enhancing the Growth, Bichemichal and Hormonal Contents in Rocket (Eruca Vesicaria Subsp. Sativa). International Journal of Plant Physiology and Biochemistry. 5 (3): 42-49.

Billard V., P. Etienne., L. Jannin., M. Garnica., F. Cruz., J. Maria., G. Mina., J. Claude Yvin., .. \& A. Ourry (2013). Two Biostimulants Derived from Algae or Humic Acid Induce Similar Responses in the Mineral Content and Gene Expression of Winter Oilseed Rape (Brassica napus L.). $J$ Plant Growth Regul. DOI 10.1007/s00344-013-9372-2.

Brown, P. \& S. Sebastian (2015). Biostimulant in Agriculture. Frontier in Plant science. Vol 6: 671 .

Buntoro, H.B., R. Rogomulyo \& S. Trisnowati (2014). Pengaruh Takaran Pupuk Kandang dan Intensitas Cahaya Terhadap Pertumbuhan dan Hasil Temu Putih (Curcuma zedoaria L.). Jurnal Vegetalika. 3 (4): 29-39.

Du Jardin, P. (2012). The Science of Biostimulant: A Bibliography Analysis. Contract 30-CE0455515/00-96, Ad Hoc Study On Bio-Stimulant Products. handle.net /2268/169257.

Hadi, F., I. J Zakaria \& Z. Syam (2016). Diversity of Macroalgae in Kasiak Gadang Island Nirwana Beach, Padang, West Sumatra, Indonesia. The Journal of Tropical Life Science. 6 (2), 97-100.

Huang, W., D. A. Ratkowsky, C. Hui., P. Wang., J. Su and P. Shi. (2019). Leaf Fresh Weight Versus Dry Weight: Which is Better for Describing the Scaling Relationship between Leaf Biomass and Leaf Area for Broad-Leaved Plants? Forests. page 10, 256.
Kasim, W.A., Hamada, E.A.M., El-Din, N.G.S., and Eskander, S. (2015). Influence of Seaweed Extracts on The Growth, Some Metabolic Activities and Yield of Wheat Grown Under Drought Stress. Int. J. Agron. Agric. Res. 7 (2): 173-189.

Katarzyna, G., M. Izabela, T. Aukasz \& C. Katarzyna (2016). Plant Growth Biostimulants Based on Different Methods of Seaweed Extraction with Water. BioMed Research International. 25 (11): 50-372.

Kavipriya, R \& T. Nallamuthu. (2012). Effect of Seaweed Liquid Fertilizers on The Biostimulan on Early Seed Germination and Growth Parameters of Oryza Sativa L. Center of Advanced Studies in Botany. INT J CURR SCI 2012, 3: 15-20. ISSN 2250-1770, India.

Kementan (2015). Produksi, Luas Panen, dan Produktivitas Padi Indonesia 2011- 2015. Kementerian Pertanian Sub Sektor Tanaman Pangan. http://www.pertanian.go.id/ap_pages/mod /datap.

Kementrian Kelautan dan Perikanan/KKP. (2015). Kelautan dan Perikanan dalam Angka 2015. Jakarta: Pusat Data, Statistik dan Informasi Kementrian Kelautan dan Perikanan (KKP).

Kumari, R., L. Kaur., and A. K. Bhatnagar. (2011). Effect of Aqueous Extract of Sargassum johnstonii Setchell \& Gardner on Growth, Yield and Quality of Lycopersicon esculentum Mill. J. Appl. Phycol. 23 (3): 623-633.

Nardi, S., D. Pizzeghello, M. Schiavon \& A. Ertani (2016). Plant Biostimulants: Physiological Responses Induced by Protein Hydrolyzed-Based Products and Humic Substances in Plant Metabolism. Sci. Agric. v.73, n.1, p.18-23, Italy.

Noli, Z. A., Mansyurdin, Izmiarti, O. Sriyuni, and S. Rimayani (2018) a. Effect of Seaweeds Extract as Biostimulant on 
Germination of Glycine max. Seminar Universitas Mulawarman, Samarinda.

Noli, Z. A., Suwirmen, and Aisyah (2018) b. Effect of Seaweeds Extract as Biostimulant on Growth of Glycine max on Ultisol, $2^{\text {nd }}$ International Conference SFRN 2018, Universitas Andalas, Padang.

Norra, L., A. Aminah, and R. Suri. (2016). Effects of Drying Methods, Solvent Extraction and Particle Size of Malaysian Brown Seaweed, Sargassum sp. on The Total phenolic and Free Radical Scavenging Activity. International Food Research Journal. 23 (4): 1558-1563.

Osman, H. E. \& O. M. A. Salem (2011). Effect of Seaweed Extracts as Foliar Spray on Sunflower Yield and Oil Content. Egyptian Journal of Phycology. 12 (2): 59-72.

Rengasamy, K. R. R., M. G. Kulkarni., S. C. Pendota., and J. V. Staden. (2016). Enhancing Growth, Phytochemical Constituents and Aphid Resistance Capacity in Cabbage with Foliar Application of Eckol - a Biologically Active Phenolic Molecule from Brown Seaweed. New Biotechnol. 33 (2): 273279.

Ronga, D., E. Biazzi., K. Parati., D. Carminati, E. Carminati and A. Tava. (2019). Microalgal Biostimulants and Biofertilisers in Crop Productions. Agronomy. Page: 8 of 22.

Sasidharan, S., Chen, Y., Saravanan, D. et al. (2011). Extraction, Isolation and Characterization of Bioactive Compounds from Plants' Extracts. Afr. J. Tradit. Complem. 8 (1): 1-10.

Stirk W. A. and J. V. Staden. (2014). Comparison of Cytokinin and Auxin Like Activity in Some Commercially Used Seaweed Extracts. J. Appl. Phycol., 8, 503-8.

Sutharsan S., S. Nishanthi and S. Srikrishnah. (2017). Effect of Seaweed (Sargassum crassifolium) Extract Foliar Application on Seedling Performances of Glycine max L. Research Journal of Agriculture and Forestry Sciences, 5 (4), 1-5, April (2017).

Tandon, S. and Dubey, A. (2015). Effects of Biozyme (Ascophyllum nodosum) Biostimulant on Growth and Development of Soybean [Glycine $\max$ (L.) Merill]. Commun. Soil Sci. Plant Anal. 46 (7): 861-874.

Yang, B., Y. Jiang, J. Shi, F. Chen, and M. Ashraf. (2011). Extraction and Pharmacological Properties of Bioactive Compounds from Longan (Dimocarpus longan Lour.) Fruit a Review, Food Research International. 44 (7): 18371842. 